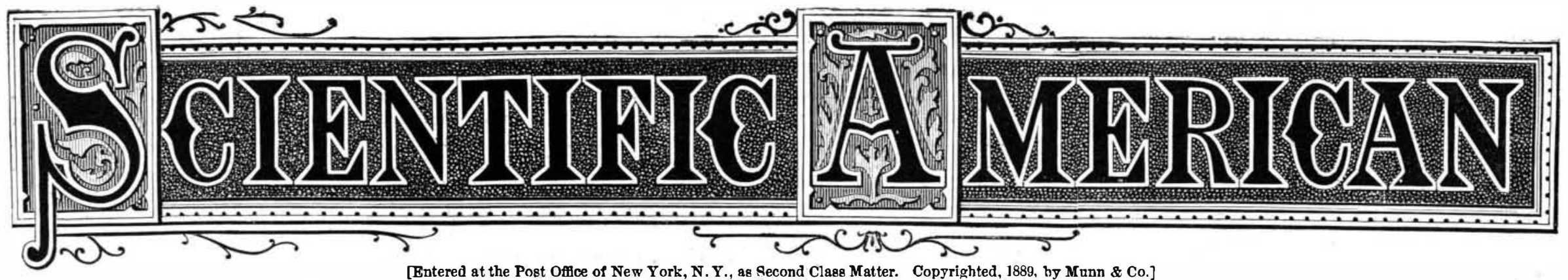

A WEEKLY JOURNAL OF PRACTICAL INFORUATION, ART, SCIENCE, MECHANICS, CHEMISTRY, AND MANUFACTURES.

Vol. LX.-NoO $14 \cdot$.

NEW YORK, APRIL 6, 1889.

[\$3.00 WEEKLY.

THE ARTESIAN WELLS OF THE JAMES RIVER VALIEY, DAKOTA.

$$
\text { L. F. KORYs. }
$$

productive farms. This valley greatly resembles the deep, with a tube 51/2 inches, made of 3-16 inch wrought valley of the Nile, but unlike that historic region has iron. Water was found in sand rock. The water is its surplus of water beneath instead of at the surface. soft, but cannot be used in boilers, as it foams. This

The James River Valley is one of the remarkable It is the greatest artesian well district known. A well choked up with sand for a time, but afterward agricultural valleys of the country. The valley proper comparison with other districts will show that for pres- opened with its original force.

extends from Yankton on the south to Jamestown sure and area over which they are found, this valley far In 1884 the city put down a well 908 feet deep, $5 \frac{8}{16}$ on the north, a distance of 300 miles. Most of this surpasses them all. There are some fine wells in France, inch tube. A system of water works was put in. The vast area is level. Entire townships can be plowed but they are found only in favored localities. Some of city, with 5,000 inhabitants, has the best of fire prowithout a single obstruction to the plow. without a single obstruction to the plow.
This ideal agricultural valley was strangely passed by \begin{tabular}{r|l|l} 
This ideal agricultural valley was strangely passed by & does the pressure equal any one of fifty wells in the the highest of buildings. Aberdeen and surrounding \\
until about 1880. At this date the bufialo had gone & James Valley. Western California, from San Diego to country are very level, so to get drainage a pumping
\end{tabular} farther west; but when the writer visited this valley near the northern boundary of the State, is proving it- system, such as Pullman, Ill., has, became necessary. early in the eighties, the prairie was dotted white with self to be a fine artesian district, but strong pressure is Last year the city put down a well for power alone. the bones of this noble animal.

found only in limited areas. Nearly every city and The system is now completed, and the result is perfect. many of the small villages from Yankton to James- The pumps have a capacity of 50,000 gallons per hour. The early pioneer found the most of Dakota in whe wells, and the majority of these have a very A float makes the pumps automatic, so that they work left the surface bare. This caused drought, but since heavy pressure. \begin{tabular}{l|l} 
left the surface bare. This caused drought, but since & heavy pressure. \\
the protection of the grasses by settlement, moisture & The pioneer well was put down at Aberdeen, March, of only a few thousand dollars this city has water
\end{tabular} has so increased that this valley is now teeming with 1882, by the C., M. \& St. P. R.R. Co. It is 961 feet

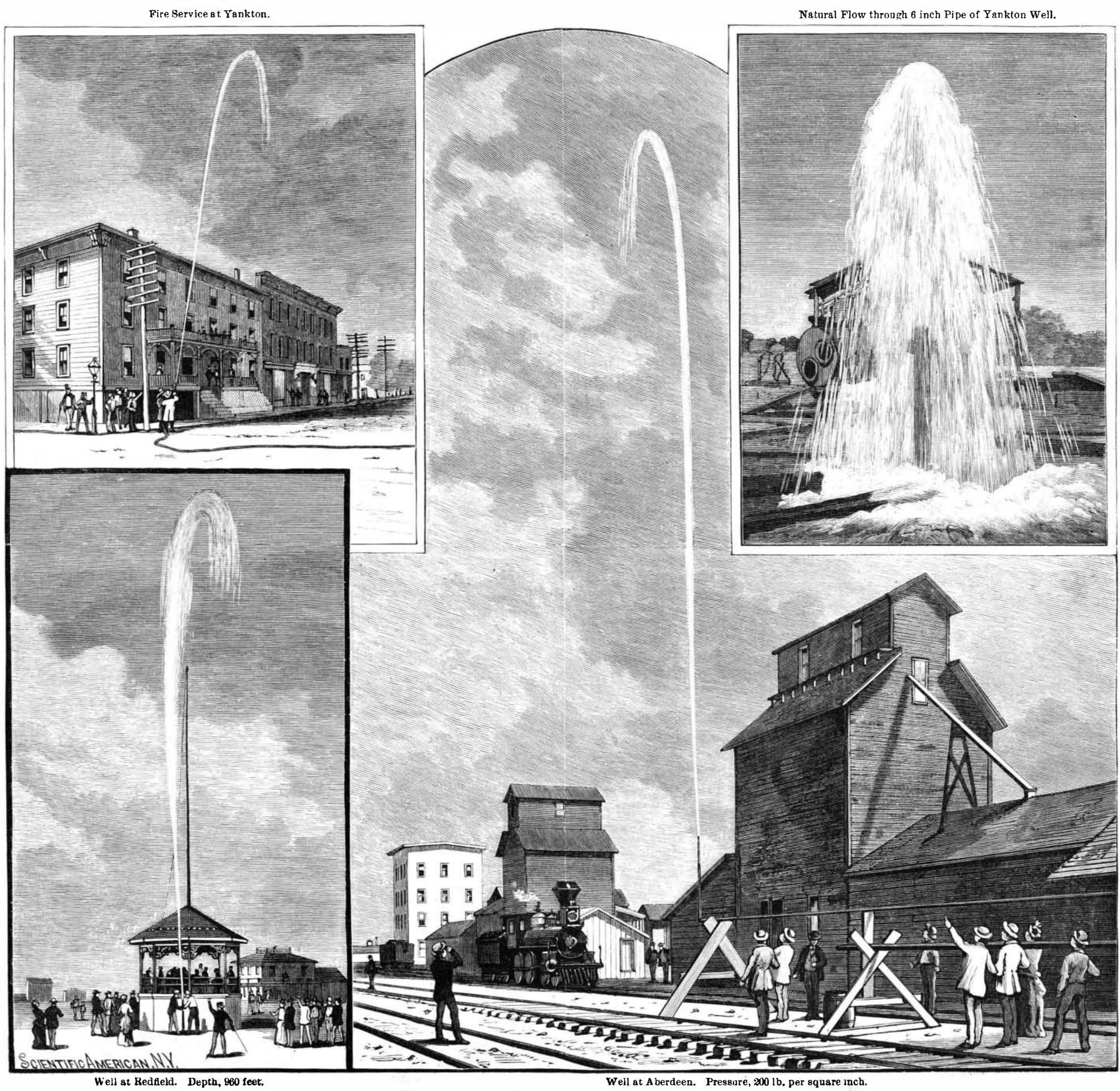

THE WONDERFOL ARTESIAN WRLLS OF DAKOTA 


\section{THE ARTESIAN WELLS OF THE JAMRS RTVER}

\section{VALLEY, DAROTA.}

(Continued from first page.)

works and a pumping sewage system without cost of fuel, engineers, or even oil. The pressure of these wells is about 200 pounds per square inci. A
vein of coal was struck in the first two wells.

Ellendale, north of Aberdeen thirty-seven miles, has a well 1.087 feet deep. Water was found in sand rock beneath an impervious stratum of shale. The water is clear and soft, with temperature of $67^{\circ}$ and pressure of 150 pounds per square inch. The city has a system of water works costing less than $\$ 7,000$.

The Redfield well is 960 feet deep. The tube in this well is of three sizes. The first 400 feet is 6 inches, the next 300 is $53 / 8$ inches, and the last 260 feet $41 / 2$ inches. ferent depths, and smelled of oil. The water is clear and soft, has temperature of $68^{\circ}$ and pressure of 200 pounds per square inch. The city has a complete system of water works for fire, lawn, and house use. It takes four strong men to hold the hose.

The Huron well is 863 feet deep, having a 6 inch tube from top to bottom. Water was found in sand rock. The pressure is upward of 200 pounds per square inch. Water is a little hard, and most of the time clear. Temperature is $60^{\circ}$. Huron has two miles of water mains and two miles of side piping. Besides furnishing water for flre use, it runs motors for two laundries and four printing offices, using about 20 horse power. The Hu-
ron and Redfield wells are perhaps the best in theron and

Yankton has two 6 inch wells, one 610 feet deep and one 600 feet deep. These wells furnish fire protection through 19,400 feet of pipes, and run the electric light, two printing presses, a tow mill, feed mill, and furniture factory. The water in these wells has a pressure of 56 pounds per square inch, and, unlike most of the other wells, is hard. It is, perhaps, the best drinking water of any of the wells in the valley. The second well did not diwinish the flow of the fir

found in sand rock, temperature $6 \%^{\circ}$.

The Jamestown well is 1,576 feet deep, and has a pressure of 100 pounds. Water is clear and soft, with temperature of $75^{\circ}$. At 300 feetquite a flow of gas was met. The city has a system of water works with the well.

The above wells are mentioned out of quite a number of equal value over a distance of 300 miles. These lie in about the center of the valley. A well at Andover, at the extreme east side of the valley, has a pressure of 100 pounds, while one at Ipswich, at the west side of the valley, has a pressure of 90 pounds. At Miller, 40 miles west of Huron, the pressure is 125 pounds. The greatest average pressure is in the center of the valley. The above figures will be at variance with the gauges as they are now found on the wells. The gauges are placed above the valve, where the pressure is greatly relieved by the overtlow. The above figures, in most cases, give full pressure.

Noted wells in other parts of the world fall far below these. The well at Belle Plain, Iowa, which got beyond control and created such a scare, had only a fraction of the power of these wells. The Belle Plain well had a pressure of only about 25 pounds per square inch, and this lessened in a few days. Water was struck at only 86 feet, and the soil above it disintegrated so easily that a hole as large as a wagon wheel was made, out of which a large quantity of water flowed, and threatened for a time disaster to the city.

The great well in the Place Hebert, Paris, France, is 2,359 feet deep and has a diameter of $3 \frac{1}{2}$ feet, yet it does not throw much over 1,000 gallons per minute, while inany wells in the James Valley throw 3,000 gatlons per minute.

The possibilities of the wells in this valley are be yond estimation. With millions of gallons flowing daily, there has been no diminution of the supply. Nature stores the supply, and it only awaits tapping and application. If one of the wells at Yankton, with a pressure of only 56 pounds, has taken the place of a 30 horse power engine, what can be done with a well with 200 pounds pressure? Then if larger bores were made, any amount of pressure desired could be obtained. Large bores should be made, because to get a certain amount of flow the valves have to be opened so wide that the water rushes out with such speed as to canse pieces of the sand rock to fly out of the well. This difflculty was met with to such an extent at Aberdeen that they were compelled to place a stone-arresting drum at the well.

That such an ideal power has not been utilized to a greater extent can only be accounted for by the fact that the country is so new. Gas was found in many of the wells. At Ashton, the cooking in a hotel is done by na tural gas. If the proper system were employed, a good supply of gas might be had.

The query arises, Whence the source of all this water? Some believe it comes from the Missouri River. This cannot be true, because at Highmore, 40 miles west of Huron, there is a well with 25 pounds pressure west of Huron, there is a well with 25 pounds pressure,
and the elevation is several hundred feet above the and the elevation is several hundred feet above the
river. At Gettysburg, only 16 miles east of the river, they have drilled 1,300 feet without getting a flow. Drillings east of the valley (in Dakota) have been unsuccessful, striking almost invariably at a few hundred feet, without getting water, the Archæan rock, which is usually the bed of artesian water. The large lake north have a less elevation. The theory is advanced
that the flow is caused by the pressure of the earth or gas upon a subterranean basin. This theory is decided ly gaseous. This would imply a hermetically inclosed space, which would soon exhaust. No such basin has been found in any of the borings. Water is found in soft sand rock, being confined above by im pervious shale. Small channels, sometimes, however, by numbers of sinall fish with eyes that have come out of two of the Aberdeen wells. Accepting, as we must, that water finds its level, and that it rises no higher unless acted upon by some externalforce, we must look to some place where the elevation and quantity are
ufficient to supply these wells. These wells are unufficient to supply these wells. These welk
doubtedly fed from the Rocky Mountains.

Great care is required in putting down these well where the pressure is so great. If any accident happens to the tubing after the full flow is met, it is almost impossible to overcome it. Nature has furnisher no valves which may be closed while the well may be revalves which may be closed while the well may be re-
paired. The wells at Frankfort and Groton are serious paired. The wells at Frankfort and Groton are serious
failures. Both of these have thrown muddy water most of the time since they were put down. The Groton well has covered acres of land with its mud, and, at one time, broke out in different parts of the town. impervious strata, and the dire consequences are har to estimate. An inch tube by way of experiment was put down in the Frankfort well about 650 feet. It came out minus 130 feet, with the point scraped on one side and bent, which indicates that it got outside of the well down about 520 feet. It also indicates a space
minus earth, as that 130 feet passed down outside of the well without meeting any resistance. The tube was put down by hand. That basin was not ther
when the well was put down. hen the well was put down.

It will be noticed that in some of the above tubings too little to resist the enormous pressure at the bottom of a well of 1,000 feet depth, having a pressure of 200 pour $₫ s$ per square inch at the surface. Water exerts a
pressure of about 43 pounds per square inch for each hundred feet in height. This would give such a well at the bottom a pressure, when the valve is closed at the top, of 630 pounds per square inch-a pressure early four times greater than a locomotive carries with a boiler twice as thick. A wisp of straw accidentally carried down 2,000 feet in the Place Hebert water like lead. Ordinarily the walls of the earth resist the pressure upon the pipes, but should a piece chip off, the pipe might burst at this point. Then there were no impervious stratum above the break,
the result might be like the two above mentioned wells.

Sometimes it is impossible to force a pipe down more than a few hundred feet. In this event a smaller tub is put down inside of the first. Sometimes as many as doree sizes are put down. When the inside pipe is pipes. These cannot be easily drawn out, owing to the riction against the walls of the earth, so an ingenious method is employed of using a left hand thread at the proper depth, enabling them to take out the top parts of the inside pipes instead. This leaves a well of telescope appearance, with small end down. The inside pipes do not necessarily, when put down, fit the outside pipes water-tight, but when separated a swedging this is not thoroughly done, the water will escape this is not thoroughly done, the water will escape,
making the flow muddy, and if, as before mentioned, there is no impervious stratum above, the water will reak out about the well.

The following analysis of the Jamestown water is Thap an index to that of most of the water:

ANALYSIS OF ARTESIAN WATERS IN DAKOTA. Jamestown-organic matter: free ammonia, 2.4 parts
per million; albuminoid ammonia, 0.046 part per milper million; albuminoid ammonia,
lion; nitrites, traces; nitrates, none.

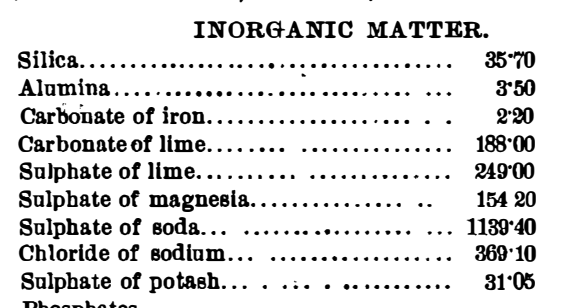

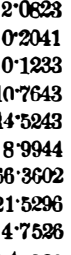
Pardness....... $31 \cdot 05$ Gorresponderte.

\section{Occultanion of Jupiter.}

To the Editor of the Scientific American:

The occultation of Jupiter by the moon yesterday morning was very successfully observed here with the 101/8 inch equatorial refractor. The sky was very clear ndeed. The first contact was noted at $18 \mathrm{~h} .45 \mathrm{~m} .47 \mathrm{~s}$. was recorded at 19 h. $37 \mathrm{n}$. $31 \mathrm{~s}$. My daughter Anna (eleven years of age), who observed the phenomenon with the three inch finder attached to the large telecope, independently recorded the first contact one second earlier than above.

Jupiter was distinctly seen, although the sun was easily visible in both telescopes.

Smith Observatory, Geneva, N. Y., March 25, 1889.

\section{English War Ships.}

There is, says the London Engineer, a vague sense of something lacking which is not pleasant, and it ems strange that notwithstanding the enormous variety in type admissible in the navy, nothing has been produced which is perfect in one respect. Thus we have nothing superlatively fast, or steady, or safe from being sunk, or able to fight her guns to perfection. Compromise is no aubt an excellent thing, but it is possible perhaps to push it too far, and it seems as though it might be worth while to abandon some qualifection. Thus, for example, it might be worth while to arm ships of the Archer class with guns which they could really use at sea; and although something else would have to be sacrificed, it might be found better in the end to raise the turret guns of the Hero, which are now, we are told, so close to the deck that the exupper deck fittings in their line of fire. As it is now. all the fittings on the fore leck leak badly, and the ess deck is always afloat when steaming against a oderate sea. A trial of the strength of these fitting hould be made by firing full charges right ahead. The great defect of the modern British navy is that we
have always tried to combine too much in one ship Our designers have behaved in effect like men wh. have to pack into one portmanteau what would fill ; they are reluctant to leave out anything, dhe result is that the whole is crushed and oiled. A very large sum is to be spent on the navy. et us hope that, instead of building half a dozen ships, in each of which half a dozen more or less incompati-
ble qualifications are to be combined somehow, the ble qualifications are to be combined somehow, the
plan will for once be tried of building half a dozen different ships in each of which will be found somesupertively good qualities.

A representative of the Iron Age paid a visit recently to the foundry of the Deoxidized Metal Company, of Bridgeport, Conn., of which L. H. Bacon is president, 0 . C. Smith is secretary and treasurer, and W. W. Keys is superintendent. The works are
equipped with 23 crucible melting holes, which are to be suped with 23 crucible melting holes, which are to beratory melting 10,000 pound charges. The foundry is to be enlarged by the addition of a building on adjoining property recently acquired, which is to be $80 \times 130$ feet, and is to be used chiefly for heavy loam work. Until now the largest castings of deoxidized bronze made were the rings of digesters for the bisulphite wood pulp process, which weighed 8,500 ppunds. Five ring and top and bottom casting composed such a digester, 22 feet long, 7 feet $81 / 2$ inches in diameter, and weighed weighing 45,000 poon larger digesters are to be made for 19 of these large and 17 small digesters. Tests made in 1886 by Dr. T. M. Drown, of the Massachusetts Institute of Technology, proved the resistance of the metal to the corrosive action of bisulphite of lime.

\section{The Late Professor Proctor.}

From a letter that has come into our hands, from the widow of the late Richard A. Proctor, it appear that the astronomer did not die of yellow fever, as has been commonly supposed, but of a low remittent malarial fever, that his wife and two of his children likewise suffered from. His son died of the same disease last November. Mrs. Proctor is desirous of making journalism a profession. As secretary and assistant editor of her husband in his literary work, she has had considerable experience, and has besides an The engravings are accurate representations of the aptitude and fondness for this class of work.

normous heights to which the water is thrown by atural pressure.

THE chemical journals announce as newly discoverec olvents of Prussian blue, molybdic acid, which dissolves it in large quantity, and molybdate and tung
state of ammonia, which also dissolve it very readily.
Mrs. Proctor has recently received a civil list pension of $\$ 500$ as the result of a memorial signed by Sir John Lubbock, the Duke of Argyle, and other prominent countrymen of the deceased. Mrs. Proctor is at present residing at her home at Corona Lodge, Orange Lake, Elorida. 